\title{
EFFECTS OF MACROECONOMIC VOLATILITY ON ECONOMIC GROWTH: EVIDENCE FROM THE EUROPEAN UNION
}

\author{
Asst. Prof. Gülçin GÜREŞÇİ \\ Dokuz Eylül University, FEAS, İzmir, Turkey, (gulcin.guresci@deu.edu.tr)
}

\begin{abstract}
This paper investigates the relationship between macroeconomic volatility and economic growth for the period from 1995 to 2015. At the literature net economic growth effect of volatility is ambiguous. In this study, the factors which are gradually affecting the economic growth are estimated. This paper also contributes to the literature by focusing on how volatility affects economic growth and gives some policy implications. It is found that economic growth is lower in the presence of volatility at the European Union countries. This shows that smoother economic policy is crucial for the stable economic growth. Uncertainty effects economic growth negatively.
\end{abstract}

Keywords: Macroeconomic Volatility, Economic Growth, European Union, Panel Data.

\section{MAKROEKONOMIK VOLATILITENIN EKONOMIK BÜYÜME ETKILERİ: AVRUPA BİRLİ̆̈I ÖRNEĞİ}

\begin{abstract}
ÖZET
Bu makale, 1995 ile 2015 arasindaki dönemde makroekonomik volatilite ile ekonomik büyüme arasındaki ilişkiyi araştırmaktadır. Literatürde volatilitenin net ekonomik büyüme etkisi belirsizdir. Bu çalışmada, ekonomik büyümeyi tedrici olarak etkileyen faktörler tahmin edilmektedir. Bu makale, ayrıca volatilitenin ekonomik büyümeyi nasıl etkilediğine odaklanarak literatüre katkıda bulunur ve bazı politika çıkarımları verir. Avrupa Birliği ülkelerinde volatilitenin varlığında ekonomik büyümenin daha düşük olduğu görülmektedir. Bu, daha istikrarlı ekonomi politikasının istikrarlı ekonomik büyüme için çok önemli olduğunu göstermektedir. Belirsizlik, ekonomik büyümeyi olumsuz etkilemektedir.
\end{abstract}

Anahtar Kelimeler: Makroekonomik Volatilite, Ekonomik Büyüme, Avrupa Birliği, Panel Veri. 


\section{Introduction}

Macroeconomic volatility has important effect on economic growth. Developing countries has high volatility, therefore to understand the reasons and effects of this, economists focused on this subject. Because of the global economic crises has made macroeconomic volatility a key issue in analyzing the determinants of economic growth. The aim of this paper is to show the impact of macroeconomic volatility on economic growth. Negative relation between output volatility and economic growth was firstly mentioned by Keynes (1936). Then one-sector neoclassical growth model shows the same negative relation. According to this model, increasing risk reduces investment demand, and this decrease will be more than the precautionary savings. Whereas Friedman (1968) says that there is no relationship between output growth and output volatility, because output growth is determined by the real production factors such as labor skills and technologic changes. On the other hand, income volatility causes to increase precautionary savings.

With the Real Business Cycle (RBC) Theory, Kyland \& Prescott (1982), economic growth and business cycle fluctuations begin to be analyzed in a unified modeling framework. Before this theory, economic growth and business cycle fluctuations were regarded as two separate issues: Solow growth model and IS-LM framework. It was believed that long-term economic growth was independent of cyclical factors. And according to the RBC theory, production shocks and variability of these disturbances is believed to have only second order effect on growth. (Dabusinskas et al, 2012: 4). And Lucas (1987) implies that temporary cyclical fluctuations have no first order implications for long-term growth. According to the Stiglitz (1993) causality between growth and volatility may be bidirectional.

It would seem natural to seek theoretical grounds for the negative relationship between volatility and economic growth in endogenous growth models. However Aghion \& Banerjee (2005) explain the two main conceptual mechanisms of endogenous growth -the AK model and the Schumpeterian paradigm- tend to suggest that volatility should affect growth positively rather than negatively. In the AK framework, the impact of volatility on economic growth is ambiguous. They said that these models need to modify by introducing imperfections in the functioning of financial markets. (Dabusniskas et al, 2012: 5). According to these models there are two reasons related with this relationship. One of them is about precautionary motives. Due to precautionary motives, higher volatility leads to higher savings. Higher savings causes to increase higher investments, and stimulates economic growth. Volatility reduces risk-adjusted returns, so it decreases economic growth. Net growth effect is ambiguous. "The net effect depends on the elasticity of inter-temporal substitution, which is usually also equal to the coefficient of relative risk aversion. At the Schumpeterian framework financial frictions are not included in the growth model. But in the real world financial markets are imperfect, and it caused to change the relations between volatility and economic growth from positive to negative.

Volatility can lead to negative effects on growth through various channels. These are factor accumulation, trade, changes in the prices of critical goods and financial system. In addition, weak financial institutions and unpredictable macroeconomic policies increased output volatility, on account of this, economic growth affect negatively. 
Bernanke (1983) emphasis that output volatility raises economic uncertainty and thus hampers investment due to its irreversible nature, which in turn leads to lower economic growth. Bernanke \& Gotler (1989) said higher volatility may increase the likelihood of binding credit constraints and thereby reduce investment with the ratio of private credit to GDP. Aghion \& Howitt (2006) found that volatility has a negative effect on growth under credit market imperfections that constrain investments during recessions.

Ramey \& Ramey (1995) found negative relationship between volatility and economic growth for 92 countries for the period from 1962 to 1985 . Dependent variable is per capita output growth. They measure realized volatility (realized volatility commonly measured by standard deviation of actual output growth) and their results show that unpredictability of economic policy has negative impact on economic growth. According to this, an increase in realized volatility causes lower per capita growth in these countries.

According to Dabusinskas et al. (2012) the negative effect of macroeconomic volatility on growth should be weaker in countries with more developed financial sectors. Similarly Aghion \& Banerjee (2005) found that when the credit ratio is higher, the negative volatility growth association is weaker (less negative). And countries which have the most financially advanced countries have positive relations. On the contrary, Mirman (1971) and Lensink et al. (1999) found that higher volatility could increase precautionary saving and therefore lead to higher growth rates. Aizenman \& Pinto (2004) found that volatility has a negative impact on poverty, through growth as well as inequality. Volatility has damaging effect on growth especially in low income countries. Dawe (1996) found positive effect of volatility on investment through it causes to increase precautionary savings. And there is a negative relationship between economic growth and volatility (through an allocation of capital to sectors with lower yields).

Giovanni \& Levchenko (2006) emphasis that the effects of volatility are not only larger in developing countries but these countries also face more macroeconomic volatility than do industrial countries, because developing countries face with bigger exogenous shocks.

Bloom et al (2012) show that uncertainty is negatively correlated with future economic activity in the short run. Afonso \& Jalles (2012) found that economic growth is lower in the presence of volatile fiscal policy. Karamelikli \& Bayar (2016) found that macroeconomic volatility and financial instability effect economic growth negatively. To gain stable economic growth rates, fiscal policies should be smoother. According to all of these researches macroeconomic volatility is an obstacle for economic growth, because macroeconomic volatility negatively impacts of investment decisions of individuals.

\section{Measuring Economic Volatility}

Macroeconomic volatility refers to variability in fiscal and monetary policies. Uncertainty and volatility have different meaning. Uncertainty describes a situation where several possible outcomes are associated with an event, but the assignment of probabilities to the outcomes is not possible. Volatility provides a measure of the possible variation or movement in a particular economic variable. It is measured by observed realizations of a random variable over the historical period. It is called realized volatility, and measured by a standard deviation based on 
the history of an economic variable (Aizenman \& Pinto, 2004: 3-4). On the other hand, some of the studies calculated volatility from the residuals of estimated equation.

Measuring economic volatility involves evaluating the deviation between the values of an economic variable and its equilibrium value. When we look at the literature, we see that variables such as GDP, terms of trade, interest rates, export revenues and prices of goods are commonly used to measure volatility. Ramey \& Ramey (1995) used the standard deviation of the growth rate of GDP per-capita. Serven (1997) used two different measure of macroeconomic volatility: standard deviation and coefficient of variation of several aggregates (trade, inflation etc.). Acemoglu et al. (2003) measured the macroeconomic volatility using standard deviations of GDP growth rates and terms of trade. In this paper macroeconomic volatility is measured as the standard deviation of the average growth rate of real GDP per capita.

\section{Data and Econometric Methodology}

To show the impact of macroeconomic volatility on economic growth, data are collected from World Economic Development Indicators. The period starts from 1995 to 2015. Second generation panel data analysis for the European Union countries is used. Only Malta is excluded from the analysis because of the lack of the data, so there is 27 countries. Balanced panel data are used. This means that there is no missing data. In this paper, average and country-specific results are estimated. This gives important policy implication for each country.

To show the relation between macroeconomic volatility and economic growth the following linear equation is used:

$$
\Delta y_{t}=\gamma \log \sigma_{t}+\beta X_{t-1}+\mu_{t}
$$

$\gamma$ shows the link between macroeconomic volatility and economic growth.

$\sigma_{t}$ is the standard deviation of the average annual growth rate of real GDP per capita.

$u_{t}$ is a white noise error term.

$X_{t-1}$ consist of $\log y_{t-1}, \Delta n_{t-1}, i_{t-1}, g_{t-1}, e_{t-1}$. All variables in $X_{t-1}$ are pre-date the period over which the real per capita GDP growth $\Delta y_{t}$ and the corresponding volatility $\sigma_{t}$ are measured. This mitigates the potential endogeneity issues in the model.

$y_{t}$ is the average annual growth rate of real GDP per capita.

$\Delta n_{t-1}$ is the average annual population growth rate

$i_{t}$ is the average annual investment share in GDP calculated as the ratio of nominal gross fixed capital formation outlays to nominal GDP.

$g_{t}$ is the average annual government share in GDP calculated as the ratio of nominal government consumption expenditures to nominal GDP.

$e_{t}$ is the average annual share in GDP calculated as the ratio of nominal exports of 
goods and services to nominal GDP.

\section{Empirical Results}

At the empirical application, Pesaran \& Yamagata's (2008) Delta test is used to examine the heterogeneity between cross section units. According to Pesaran \& Yamagata (2008) following equation is estimated:

$$
y_{i t}=\alpha_{i} \tau_{T}+X_{i} \beta_{i}+\varepsilon_{1, i}, \quad \forall i=1,2, \ldots, N
$$

where $\tau_{T}$ indicates Tx 1 vector of ones, $\beta_{i}$ is $\mathrm{kx} 1$ vector of unknown slope coefficient, $y_{i}=\left(y_{i 1}, \ldots, y_{i T}\right)^{\prime}, x_{i}=\left(x_{i 1}, \ldots, x_{i T}\right)^{\prime}$, and $\varepsilon_{1, i}=\left(\varepsilon_{i 1}, \ldots, \varepsilon_{i T}\right)^{\prime}$.

$$
\begin{aligned}
& H_{0}: \beta_{i}=\beta \\
& H_{1}: \beta_{i} \neq \beta
\end{aligned}
$$

If null hypothesis is rejected, then series are heterogeneous. The results show that our series are heterogeneous.

Table 1: Delta Test Results

\begin{tabular}{lcl}
\hline Delta_tilde: & 10.827 & prob $=0.000$ \\
\hline Delta_tilde_adj: & 11.97 & prob $=0.000$ \\
\hline
\end{tabular}

After checking the heterogeneity, Cross-section dependence (CD) test of Pesaran (2004) was used, Table 2 shows the CD test results.

Table 2: Cross Section Dependence Test

\begin{tabular}{cc}
\hline Variable & Test Statistics \\
\hline$g d p_{t}$ & $11.354 * * *$ \\
\hline$e_{t}$ & $6.316^{* * *}$ \\
\hline$g_{t}$ & $5.872 * * *$ \\
\hline$i_{t}$ & $3.224 * * *$ \\
\hline$n_{t}$ & $7.952^{* * *}$ \\
\hline$v_{t}$ & $8.086 * * *$ \\
\hline
\end{tabular}

Note: $* * *$ indicates that the coefficient is significant at $1 \%$.

CD Test results show that there is cross section dependence for all series. Therefore Pesaran's Cross-Sectionally Augmented Im, Peseran, Shin (CIPS) Test should be used, as for this test takes into consideration of cross section dependence. 
Table 3: CIPS Test Results

\begin{tabular}{cc}
\hline Variable & Test Statistics \\
\hline$g d p_{t}$ & -2.62 \\
\hline$e_{t}$ & -1.7512 \\
\hline$g_{t}$ & 1.2795 \\
\hline$i_{t}$ & 1.7412 \\
\hline$n_{t}$ & 2.2254 \\
\hline$v_{t}$ & 2.8104 \\
\hline
\end{tabular}

According to the CIPS Test results, null hypothesis of non-stationary is not rejected a 1 or 5 per cent level of all series. It means that there is unit root problem. The series have cross sectional dependence, so Westerlund's (2008) second generation panel cointegration test is used. This test gives more powerful results than other panel cointegration test while there are cross sectional dependence.

Table 4: Durbin-H (2008) Cointegration Tests Results

\begin{tabular}{|c|c|c|}
\hline & Test Statistics & Probability \\
\hline Durbin-H group & 13.725 & 0.000 \\
\hline Durbin-H panel & 2.844 & 0.000 \\
\hline
\end{tabular}

Table 4 shows that there is a cointegration relationship. Based on the cointegration relationship and cross section dependence of the series, Pesaran's (2006) Common Correlated Effects Mean Group (CCE-MG) is used to estimate the coefficients. Table 5 shows the CCE$\mathrm{MG}$ estimation results.

Table 5: Pesaran's CCE Mean Group Estimates

\begin{tabular}{lccc}
\hline $\ln y_{t}$ & Coefficient & se(NP) & t(NP) \\
\hline $\ln v_{t}$ & -0.692976 & 0.073671 & 9.406258 \\
\hline $\ln x_{t}$ & 0.130369 & 0.046192 & 2.822342 \\
\hline $\ln p_{t}$ & -0.37906 & 0.653203 & -0.58032 \\
\hline $\ln k_{t}$ & 0.255253 & 0.091211 & 2.798492 \\
\hline $\ln c_{t}$ & -0.31498 & 0.101634 & -3.09921 \\
\hline
\end{tabular}

According to the CCE-Mean Group estimation results, the coefficient of volatility is economically significant. It is found that there is a negative relationship between volatility and economic growth for 27 EU countries. This negative link is statistically significant. Other control variables' coefficients are consistent with the expected signs. 
Table 6: CCE Estimation Results for Each Country

\begin{tabular}{|c|c|c|c|c|c|}
\hline Country & $\ln v_{t}$ & $\ln x_{t}$ & $\ln p_{t}$ & $\ln k_{t}$ & $\operatorname{lnc} c_{t}$ \\
\hline Austria & $-0.901 * * *$ & -0.151 & $-3.388 * * *$ & $-0.397 * * *$ & -0.367 \\
\hline Belgium & $-0.526 * * *$ & -0.083 & -0.198 & $0.495 * * *$ & $-1.346 * * *$ \\
\hline Bulgaria & 0.112 & -0.012 & 0.534 & $0.209 * * *$ & $0.194 * * *$ \\
\hline Croatia & $-0.813 * * *$ & $0.324 * *$ & -0.107 & 0.203 & $0.644 * * *$ \\
\hline Cyprus & $-1.131 * * *$ & $-0.12 * * *$ & $5.895 * * *$ & $-0.09 * * *$ & $-0.196 *$ \\
\hline Denmark & $-1.412 * * *$ & $-0.197 * *$ & $1.947 * *$ & -0.21 & $-0.261 *$ \\
\hline Czechia & 0.15 & $0.526 * * *$ & 2.756 & 0.242 & 0.147 \\
\hline Estonia & $-0.876 * * *$ & 0.022 & $3.48 * * *$ & 0.121 & $-0.959 * * *$ \\
\hline France & $-0.897 * * *$ & -0.022 & $-2.241 * * *$ & 0.384 & -0.65 \\
\hline Finland & $-0.467 * * *$ & 0.062 & $5.567 * * *$ & $1.192 * * *$ & -0.059 \\
\hline Greece & $-1.392 * * *$ & 0.026 & 0.093 & 0.056 & $-0.169 * * *$ \\
\hline Germany & $-0.861 * * *$ & $0.381 * *$ & -0.06 & $0.923 * * *$ & -0.038 \\
\hline Hungary & 0.382 & -0.001 & -0.263 & $1.325^{* * *}$ & $0.226 * * *$ \\
\hline Ireland & $0.383 *$ & $0.082 *$ & $-6.921 * * *$ & $1.17 * * *$ & $0.51 * * *$ \\
\hline Italy & $-1.255 * * *$ & 0.072 & $-0.268 *$ & -0.119 & 0.016 \\
\hline Latvia & 0.288 & $0.452 * * *$ & -0.802 & 0.363 & $-0.739 * * *$ \\
\hline Lithuania & $-0.759 * * *$ & $0.358 * * *$ & 0.351 & $-0.609 * * *$ & $-0.89 * * *$ \\
\hline Luxembourg & $-1.29 * * *$ & -0.059 & $-10.221 * * *$ & $-0.335^{*}$ & -0.204 \\
\hline Netherlands & $-0.799 * * *$ & 0.047 & -0.566 & 0.332 & $-0.941 * * *$ \\
\hline Romania & $0.411 *$ & $0.273 * *$ & -0.662 & -0.092 & $-1.179 * * *$ \\
\hline Poland & -0.484 & 0.271 & 1.313 & 0.265 & $-0.762 * * *$ \\
\hline Slovak Republic & 0.22 & $0.455^{* * *}$ & 3.787 & $0.275^{* * *}$ & $0.643 * * *$ \\
\hline Slovenia & $-0.89 * * *$ & -0.137 & -1.235 & 0.072 & $-0.575 * * *$ \\
\hline Spain & $-0.314 * * *$ & $0.247 * * *$ & $-3.073 * * *$ & $0.362 * * *$ & $-0.636 * * *$ \\
\hline Portugal & $0.288^{*}$ & $0.556 * * *$ & $-3.574 *$ & $0.333 * * *$ & -0.326 \\
\hline Sweden & $-0.728 * * *$ & $0.419 * * *$ & -0.625 & $0.534 * * *$ & -0.459 \\
\hline United Kingdom & $-0.681 * * *$ & $-0.271 * * *$ & -1.756 & -0.11 & -0.129 \\
\hline
\end{tabular}

Note: $* * *, * * *$ indicates that the coefficient is significant at $1 \%, 5 \%$ and $10 \%$ respectively.

There is substantial variation across countries; volatility has negative relationship between growth except in Bulgaria, Ireland and Romania. The coefficients are not statistically significant for Bulgaria, Czechia, Hungary, Latvia, Poland and Slovak Republic. France is the lowest variance country, and Estonia is the highest variance country. When we look at 
the results we see that there is substantial variation in the volatility across countries, and that volatility has a negative relationship with growth.

\section{Conclusion and Recommendations}

This paper considers the linkages between macroeconomic volatility and economic growth for the sample of the $27 \mathrm{EU}$ countries for the period 1995 to 2015 . It is found that there is a negative growth effect of macroeconomic volatility in line with the theoretical arguments. In addition to this, investigates the affects of population, investment, government expenditures, and openness for each country and for the EU as a whole.

This paper confirms that Ramey \& Ramey's (1995) and related contemporary studies' results which indicate the negative relationship between macroeconomic volatility and economic growth. Via using these estimates, we are able to see which countries have higher negative volatility affect on economic growth.

This paper emphases uncertainty effects economic growth negatively. Therefore, macroeconomic policies should be aims macroeconomic stability. This paper is also important because it shows the country-specific results at the long-run with using CCE-MG model, and this contribution gives crucial information for each EU countries.

\section{References}

Acemoglu, D., Johnson, S., Robinson, J., \& Thaicharoen, Y. (2003). Institutional causes, macroeconomic symptoms: Volatility, crises and growth. Journal of Monetary Economics, 50(1), 49-123.

Afonso, A., \& Joao T. J. (2012). Fiscal volatility, financial crises and growth. ISEG Economics Working Paper, 6, 1-9.

Aghion, P., \& Howitt, P. (2006). Joseph Schumpeter lecture appropriate growth policy: A unifying framework. Journal of the European Economic Association, 4(2-3), 269-314.

Aizenman, J., \& Pinto, B. (2004). Managing volatility and crises: A practitioner's guide overview. National Bureau of Economic Research. Working Paper, 10602, 1-40.

Bernanke, B. S. (1983). Irreversibility, uncertainty, and cyclical investment. The Quarterly Journal of Economics, 98(1), 85-106.

Bloom, N., Floetotto, M., \& Jaimovich, N. (2012). Really uncertain business cycles. NBER Working Paper, 18245, 1-55.

Dabusinskas, A., Kulikov, D., \& Randveer, M. (2012). The impact of volatility on economic growth. Eesti Pank Working Paper Series, 7/2012, 1-19.

Dawe, D. (1996). A new look at the effects of export instability on investment and growth. World Development, 24(12), 1905-1914.

Friedman, M. (1968). The role of monetary policy. American Economic Review, 58, 1-17.

Giovanni, J., \& Levchenko, A. (2006). Openness, volatility and the risk content of exports. Society for Economic Dynamics 2006, Meeting Papers, 86, 1-58. 
Karamelikli, H., \& Bayar, Y. (2016). Makroekonomik ve finansal istikrarın ekonomik büyüme üzerindeki etkisi: Türkiye örneği. International Journal of Management, Economics and Business, ICAFR 16, Special Issue, 225-236.

Lensink, R., Bo, H., \& Sterken, E. (1999). Does uncertainty affect economic growth? An empirical analysis. Review of World Economics, 135(3), 379-396.

Mirman, L.J. (1971). Uncertainty and optimal consumption decisions. Econometrica, 39(1), 179-85.

Ramey, G., \& Ramey, V.A. (1995). Cross-country evidence on the link between volatility and growth. The American Economic Review, 85(5), 1138-1151.

Sandmo, A. (1970). The effect of uncertainty on saving. Review of Economic Studies, 37, $312-$ 320.

Serven, L. (1997). Uncertainty, volatility, and irreversible investment: Theory, evidence, and lessons for Africa. Journal of African Economies, 6(3), 229-268. 
